\title{
Quality Assessment of Emergency Corrective Maintenance of Critical Care Ventilators within the Context of COVID-19 in São Paulo, Brazil
}

\author{
By A. E. L. Alvarado', D. A. O. Rosa', S. G. Mello², M. S. Dias², M. F. Barbosa², K. N. Barros², B. A. Lemos², R. L. Vitorasso', V. \\ P. Bartholomeu' ${ }^{1}$, P. P. Americano ${ }^{1}$, E. S. Filho ${ }^{1}$, J. C. T. Barros Moraes ${ }^{1}$, A. F. G. Ferreira Junior ${ }^{2}$, H. T. Moriya ${ }^{1}$ \\ ${ }^{1}$ Escola politécnica, University of São Paulo, Brazil \\ ${ }^{2}$ Institute for Technological Research, São Paulo, Brazil
}

\begin{abstract}
This technical report presents the quality assessment process for the emergency corrective maintenance of critical care ventilators in a node, IPT-POLI, of a voluntary network that is part of the initiative +Maintenance of Ventilators, led by the National Service of Industrial Training (SENAI) and its Integrated Manufacturing and Technology Center (CIMATEC) to perform maintenance on unused mechanical ventilators in the context of the COVID-19 pandemic in Brazil. A procedure was established for the quality assessment of equipment subjected to corrective emergency maintenance, covering the essential aspects of the three primary standards (ABNT NBR IEC 60601-1: 2010+A1:2016, ABNT NBR ISO IEC 62353: 2019, and ABNT NBR ISO 80601-2-12:2014) for performance and safety assessment. A set of nine critical care ventilators was evaluated considering the following parameters: leakage current, protective ground resistance, control accuracy, delivered oxygen test, and alarms. The evaluated ventilators underwent corrective emergency maintenance before performance and safety assessments. In the electrical safety tests, all equipment presented values prescribed for the standard. However, the assessment of ventilator parameters revealed that their performance was below the standard. Finally, quality assessment reports were sent to the clinical engineering departments at hospitals. Thus, it can be concluded that criteria selection for the quality assessment in critical care ventilators is crucial and of great significance for future pandemic scenarios, such as the situation experienced during the COVID-19 pandemic.
\end{abstract}

Keywords - Quality assessment, critical care ventilators, standards, corrective maintenance, ventilation modes, COVID-19.

Copyright ( ( 2021. This is an open-access article distributed under the terms of the Creative Commons Attribution License (CC BY): Creative Commons - Attribution 4.0 International - CC BY 4.0. The use, distribution or reproduction in other forums is permitted, provided the original author(s) and the copyright owner(s) are credited and that the original publication in this journal is cited, in accordance with accepted academic practice. No use, distribution or reproduction is permitted which does not comply with these terms.

\section{INTRODUCTION}

Faced with the pandemic due to the novel coronavirus (SARS-CoV-2), the Brazilian health system experienced limitations in the number of critical care ventilators due to the increased demand. These ventilators were fundamental for the treatment of patients suffering from the most severe levels of the disease. The number of beds in intensive care units at hospitals was monitored as the disease progressed, and it was observed that certain regions had insufficient capacity. ${ }^{1}$

The Institute of Technological Research (IPT) and the Escola Politecnica (POLI) of the University of São Paulo set up a laboratory (IPT-POLI) to perform maintenance, inspection, electrical safety tests, and quality assessment 
of mechanical ventilators to provide support to public hospitals in São Paulo, Brazil. Medical devices that were unusable due to technical failures were repaired and returned to hospitals. There was a voluntary network of 39 maintenance points in all Brazilian states, that are part of the national initiative (+Maintenance of Ventilators) led by the National Service of Industrial Training and its Integrated Manufacturing and Technology Center.

The maintenance and quality assessment processes were based on ABNT NBR 77, ABNT NBR ISO IEC 62353: 2019, and ABNT NBR ISO 80601-2-12:2014. This technical report addresses the quality assessment process conducted during the first months of activity and the set of critical tests selected as criteria for quality assessment after the maintenance process.

Specific electrical safety tests were conducted per ABNT NBR IEC 60601-1: 2010+A1:2016 (general requirements for basic safety and essential performance). The selected tests were leakage current to earth, to the patient, and in the medical device enclosure, considering the manufacturer's classification in accompanying documents. ${ }^{2}$

Another essential standard used for evaluation was ABNT NBR ISO IEC 62353: 2019 (recurrent test and test after repair of medical electrical equipment) that presents the requirements to be analyzed before the medical device is put into service, during maintenance and inspection, and after repair. ${ }^{3}$

The ABNT NBR ISO 80601-2-12:2014 (particular requirements for basic safety and essential performance of critical care ventilators) provides tests to evaluate ventilation modes, analyzed according to the pressure, volume, breath rate, inspiratory time, and oxygen concentration measurements. Also, the standard prescribes testing to describe several failure conditions and alarm verification, emphasizing alarm priorities. ${ }^{4}$

Critical care ventilators are medical life support devices, and the maintenance and calibration processes must be evaluated carefully to guarantee electrical safety and essential performance in ventilation. However, in the crisis scenario, it was not possible to thoroughly conduct all recommended tests; hence, there was a need for a study to select the points considered critical within a set of standards.

A procedure for quality assessment of equipment subjected to corrective emergency maintenance was developed, covering the main aspects of the three standards for performance and safety assessment. This procedure was applied to a small set of critical care ventilators, and the results are presented and discussed.

\section{METHODS}

The Electrical and Optical Equipment Laboratory of IPT and the Testing and Calibration Division of POLI were used to regularly conduct electrical safety tests on medical equipment before the COVID-19 pandemic and joined skilled labor metrology systems for this endeavor. IPT-POLI organized four areas inside the IPT campus (São Paulo, Brazil) to conduct maintenance and quality assessment procedures. A brief description of these areas is presented below. The medical devices were registered and disinfected in a reception area. After $12 \mathrm{~h}$, critical care ventilators were transferred to the waiting area, which is also utilized to store devices that were not compliant with the requirements. Then, maintenance and quality assessment procedures were performed in the service area. This two-room area had four workbenches, two for electrical safety evaluation and two for ventilation assessment. Two oxygen gas cylinders, medical oxygen (99 $\%$ ) and high-purity oxygen (99.995\%), of $10 \mathrm{~m}^{\wedge} 3$ with two-stage regulators (from 4-6 bar) (PRG-108, Prostar, Brazil) and an air compressor (1201BF, SCHULZ, Brazil) were connected to a delivery system in the service area to supply oxygen and air. Compressed air and oxygen lines were installed to supply an adjustable pressure between 4.5-5.5 bar on each workbench to accommodate critical care ventilators. Finally, compliant medical devices are stored in the dispatch area.

\section{Leakage current measurement}

An electrical safety analyzer (601 Pro Series, Fluke, USA) was used to perform the tests. Briefly, the test consisted of supplying the medical device with $110 \%$ of the rated electrical voltage, measuring the leakage current under normal conditions for all parts indicated by the ABNT NBR IEC 60601-1: 2010+A1:2016 (leakage current to 
Alvarado, Rosa, Mello, Dias, Barbosa, Barros, Lemos, Vitorasso, Bartholomeu, Americano, Filho, Barros Moraes, Ferreira Junior, Moriya: Quality Assessment of Emergency Corrective Maintenance of Critical Care Ventilators within the Context of COVID-19 in São Paulo, Brazil

earth, to the patient, and the enclosure). The test must be repeated by applying the electrical failures prescribed for the standard and measuring the corresponding leakage current. Critical care ventilators in this study, per the manufacturer, were classified as Class I. This classification refers to medical equipment that has basic insulation and grounding protection against electrical shock. The standard also provides the permitted limits for Class I equipment: leakage current $(<5 \mathrm{~mA})$, patient leakage current $(<10 \mu \mathrm{A})$, and enclosure leakage current $(<100 \mu \mathrm{A})$.

\section{Resistance of protective ground}

An electrical safety analyzer (19032, CHROMA, Germany) was used to perform the tests. The test consisted of circulating an alternating current of $25 \mathrm{~A}$ through the medical device. The ABNT NBR IEC 62353: 2019 standard was used for this test. The resistance of the protective ground was measured with an electrical safety analyzer and must be less than or equal to $300 \mathrm{~m} \Omega$ for equipment with a detachable power-supply cord.

\section{Accuracy of control: Volume control and Pressure control inflation type}

The prescriptions related to volume control and pressure control inflation type correspond to items 201.12.1.101 and 201.12.1.102 of ABNT NBR ISO IEC 80601-2-12: 2014. To test the volume control inflation type, it is necessary to measure the volume $(\mathrm{mL})$, inspiratory time $(\mathrm{s})$, positive end expiratory pressure $(P E E P)(\mathrm{hPa})$, respiratory rate (breaths/min), and fraction of inspiratory oxygen $\left(\mathrm{FiO}_{2}\right)$ $(\%)$. For the pressure control inflation type, it is necessary to measure pressure (hPa), inspiratory time (s), PEEP $(\mathrm{hPa})$, respiratory rate (breaths/min), and $\mathrm{FiO}_{2}(\%)$.

During the first month (April), to verify the accuracy

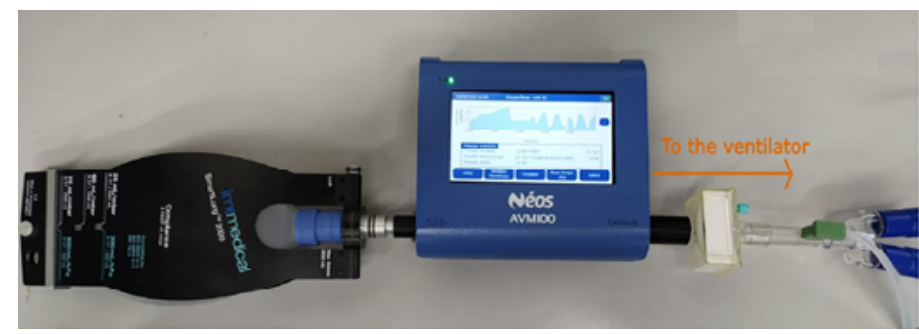

FIGURE 1. Experimental setup with the adult test lung and the ventilator tester. The orange arrow indicates the direction of the ventilator.

of control, the setup was adopted as described in items 201.12.1.101 and 201.12.1.102 with modifications in resistance and compliance values, as shown in Figure 1. A ventilator tester (AVM100, NÉOS, Brazil) was used for data acquisition. An adult test lung (SmartLung Adult 2000, IMTMedical, Switzerland), an air compressor, and gas cylinders of medical oxygen (99\%), and high-purity oxygen (99.995 \%) were applied to vary some parameters, such as compliance $(\mathrm{mL} / \mathrm{hPa})$, resistance $(\mathrm{hPa} / \mathrm{L} / \mathrm{s})$, airflow (L/min), pressure (hPa), and $\mathrm{FiO}_{2}(\%)$.

Tables 1 and 2 list the parameters set for the critical care ventilators and test lungs. Dark gray columns represent the parameters adjusted in the test lung, and light gray columns denote the parameters configured in the critical care ventilator.

TABLE 1. Adaptation of volume control inflation-type testing from item 201.12.1.101 of the ABNT NBR ISO IEC 80601-2-12: 2014

\begin{tabular}{|c|c|c|c|c|c|c|c|}
\hline \multirow[b]{2}{*}{$\begin{array}{c}\text { Test } \\
\text { Number }\end{array}$} & \multicolumn{2}{|c|}{ Test lung parameters } & \multicolumn{5}{|c|}{ Ventilator Parameters } \\
\hline & $\begin{array}{l}\text { Compliance* } \\
\text { (mL/bar) }\end{array}$ & $\begin{array}{c}\text { Linear } \\
\text { Resistance }^{*} \\
(\mathbf{h P a} / \mathrm{L} / \mathrm{s})\end{array}$ & $\begin{array}{l}\text { Volume } \\
\text { (ml) }\end{array}$ & $\begin{array}{c}\text { Inspiratory } \\
\text { Time (s) }\end{array}$ & $\begin{array}{c}\text { Set rate } \\
\text { (breaths/min) }\end{array}$ & $\begin{array}{c}\mathrm{FiO}_{2} \\
(\%)\end{array}$ & $\begin{array}{l}\text { PEEP } \\
(\mathrm{hPa})\end{array}$ \\
\hline 1 & 60 & 5 & 500 & 1 & 20 & 21 & 5 \\
\hline 2 & 60 & 20 & 500 & 1 & 20 & 21 & 10 \\
\hline 3 & 25 & 5 & 500 & 1 & 20 & 21 & 5 \\
\hline 4 & 25 & 20 & 500 & 1 & 20 & 21 & 10 \\
\hline 5 & 25 & 20 & 300 & 1 & 20 & 21 & 5 \\
\hline 6 & 25 & 50 & 300 & 1 & 20 & 21 & 10 \\
\hline
\end{tabular}

$\left(^{*}\right)$ Modified values of compliance and resistance. 
Alvarado, Rosa, Mello, Dias, Barbosa, Barros, Lemos, Vitorasso, Bartholomeu, Americano, Filho, Barros Moraes, Ferreira Junior, Moriya: Quality Assessment of Emergency Corrective Maintenance of Critical Care Ventilators within the Context of COVID-19 in São Paulo, Brazil

TABLE 2. Adaptation of pressure control inflation-type testing from item 201.12.1.102 of the ABNT NBR ISO IEC 80601-2-12: 2014

\begin{tabular}{|c|c|c|c|c|c|c|c|}
\hline \multirow[b]{2}{*}{$\begin{array}{c}\text { Test } \\
\text { Number }\end{array}$} & \multicolumn{2}{|c|}{ Test lung parameters } & \multicolumn{5}{|c|}{ Ventilator Parameters } \\
\hline & $\begin{array}{c}\text { Compliance } \\
\text { (mL/bar) }\end{array}$ & $\begin{array}{c}\text { Linear } \\
\text { Resistance }^{*} \\
(\mathrm{hPa} / \mathrm{L} / \mathrm{s})\end{array}$ & $\begin{array}{c}\text { Pressure }^{\star *} \\
\text { (hPa) }\end{array}$ & $\begin{array}{c}\text { Inspiratory } \\
\text { Time (s) }\end{array}$ & $\begin{array}{c}\text { Set rate } \\
\text { (breaths/min) }\end{array}$ & $\begin{array}{c}\mathrm{FiO}_{2} \\
(\%)\end{array}$ & $\begin{array}{l}\text { PEEP } \\
(\mathbf{h P a})\end{array}$ \\
\hline 1 & 60 & 5 & 10 & 1 & 20 & 21 & 5 \\
\hline 2 & 60 & 20 & 15 & 1 & 20 & 21 & 10 \\
\hline 3 & 25 & 5 & 25 & 1 & 20 & 21 & 5 \\
\hline 4 & 25 & 20 & 25 & 1 & 20 & 21 & 10 \\
\hline 5 & 25 & 20 & 15 & 1 & 20 & 21 & 5 \\
\hline 6 & 25 & 50 & 25 & 1 & 20 & 21 & 10 \\
\hline
\end{tabular}

(*) Modified values of compliance and resistance.

$\left.{ }^{* *}\right)$ Set pressure above PEEP level.

In May, IPT-POLI acquired another test lung simulator (Dual Adult TTL, Michigan, USA). The instrument made it possible for the laboratory to verify the control's accuracy (items 201.12.1.101 and 201.12.1.102) of critical care ventilators without any modification of resistance and compliance (Tables 3 and 4). Also, the capability of the test lung simulator increased the number of tests from six to eight. Figure 2 illustrates the experimental setup with the test lung simulator and the ventilator tester for this case.

Based on the ABNT NBR ISO IEC 80601-2-12:2014, all critical care ventilators must declare in their instructions for use the maximum error to expiratory volume, airway pressure $\left(\mathrm{P}_{\mathrm{aw}}\right), P E E P$, respiratory rate, inspiratory time,

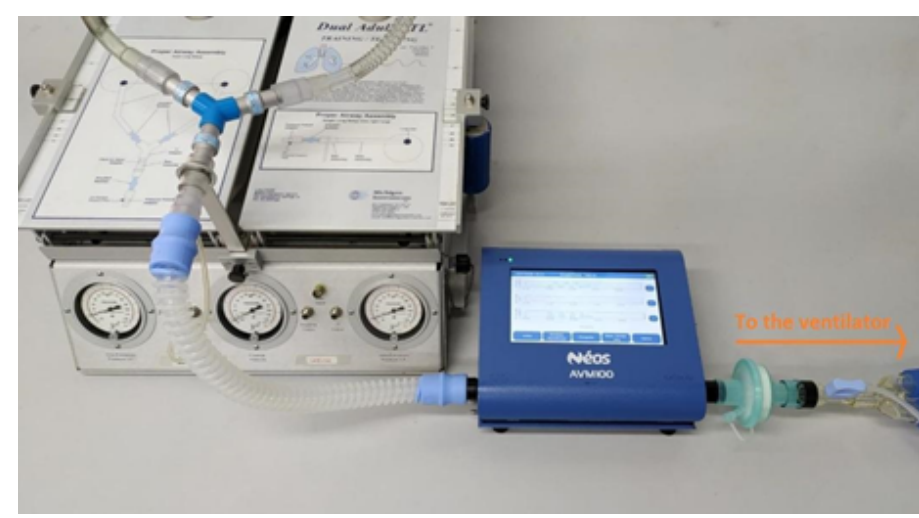

FIGURE 2. Test setup using test lung simulator (Dual Adult TTL, Michigan, USA). The orange arrow indicates the direction of the ventilator. and oxygen concentration.

TABLE 3. Volume control inflation-type testing of item 201.12.1.101 of the ABNT NBR ISO IEC 80601-2-12: 2014

\begin{tabular}{|c|c|c|c|c|c|c|c|}
\hline \multirow{2}{*}{$\begin{array}{c}\text { Test } \\
\text { Number }\end{array}$} & \multicolumn{2}{|c|}{ Test lung parameters } & \multicolumn{5}{c|}{ Ventilator Parameters } \\
\cline { 2 - 9 } & $\begin{array}{c}\text { Compliance } \\
(\mathbf{m L} / \mathbf{b a r})\end{array}$ & $\begin{array}{c}\text { Linear } \\
\text { Resistance } \mathbf{( h P a}_{\mathbf{L} / \mathbf{s})}\end{array}$ & $\begin{array}{c}\text { Volume } \\
(\mathbf{m l})\end{array}$ & $\begin{array}{c}\text { Inspiratory } \\
\text { Time } \mathbf{( s )}\end{array}$ & $\begin{array}{c}\text { Set rate } \\
(\mathbf{b r e a t h} / \mathbf{m i n})\end{array}$ & $\begin{array}{c}\mathbf{F i O}_{\mathbf{2}} \\
(\mathbf{\%})\end{array}$ & $\begin{array}{c}\text { PEEP } \\
(\mathbf{h P a})\end{array}$ \\
\hline 1 & 50 & 5 & 500 & 1 & 20 & 21 & 5 \\
\hline 2 & 50 & 20 & 500 & 1 & 20 & 21 & 10 \\
\hline 3 & 20 & 5 & 500 & 1 & 20 & 21 & 5 \\
\hline 4 & 20 & 20 & 500 & 1 & 20 & 21 & 10 \\
\hline 5 & 20 & 20 & 300 & 1 & 20 & 21 & 5 \\
\hline 6 & 20 & 50 & 300 & 1 & 20 & 21 & 10 \\
\hline 7 & 10 & 50 & 300 & 1 & 20 & 21 & 10 \\
\hline 8 & 10 & 20 & 200 & 1 & 20 & 21 & 5 \\
\hline
\end{tabular}


Alvarado, Rosa, Mello, Dias, Barbosa, Barros, Lemos, Vitorasso, Bartholomeu, Americano, Filho, Barros Moraes, Ferreira Junior, Moriya: Quality Assessment of Emergency Corrective Maintenance of Critical Care Ventilators within the Context of COVID-19 in São Paulo, Brazil

TABLE 4. Pressure control inflation-type testing of item 201.12.1.102 of the ABNT NBR ISO IEC 80601-2-12: 2014

\begin{tabular}{|c|c|c|c|c|c|c|c|}
\hline \multirow{2}{*}{$\begin{array}{c}\text { Test } \\
\text { Number }\end{array}$} & \multicolumn{2}{|c|}{ Test lung parameters } & \multicolumn{5}{c|}{ Ventilator Parameters } \\
\cline { 2 - 9 } & $\begin{array}{c}\text { Compliance } \\
(\mathbf{m L} / \mathbf{b a r})\end{array}$ & $\begin{array}{c}\text { Linear } \\
\text { Resistance } \\
(\mathbf{h P a} / \mathbf{L} / \mathbf{s})\end{array}$ & $\begin{array}{c}\text { Pressure } \\
(\mathbf{h P a})\end{array}$ & $\begin{array}{c}\text { Inspiratory } \\
\text { Time (s) }\end{array}$ & $\begin{array}{c}\text { Set rate } \\
(\mathbf{b r e a t h s / m i n )})\end{array}$ & $\begin{array}{c}\text { FiO }_{2} \\
(\mathbf{\%})\end{array}$ & $\begin{array}{c}\text { PEEP } \\
(\mathbf{h P a})\end{array}$ \\
\hline 1 & 50 & 5 & 10 & 1 & 20 & 21 & 5 \\
\hline 2 & 50 & 20 & 15 & 1 & 20 & 21 & 10 \\
\hline 3 & 20 & 5 & 25 & 1 & 20 & 21 & 5 \\
\hline 4 & 20 & 20 & 25 & 1 & 20 & 21 & 10 \\
\hline 5 & 20 & 20 & 15 & 1 & 20 & 21 & 5 \\
\hline 6 & 20 & 50 & 25 & 1 & 20 & 21 & 10 \\
\hline 7 & 10 & 50 & 30 & 1 & 20 & 21 & 5 \\
\hline 8 & 10 & 20 & 25 & 1 & 20 & 21 & 10 \\
\hline
\end{tabular}

(*) Set pressure above PEEP level.

\section{Delivered oxygen test}

A ventilator tester (AVM100, NÉOS, Brazil) and the lung test were used, as shown in Figures 1 and 2 to check the oxygen sensor on the critical care ventilator. The test lung (SmartLung Adult 2000, IMTMedical, Switzerland) was adjusted to a resistance of $5 \mathrm{hPA} / \mathrm{L} / \mathrm{s}$ and compliance of 60 $\mathrm{mL} / \mathrm{hPA}$; in the case of the test lung simulator (Dual Adult TTL, Michigan, USA), it was configured with a resistance of $5 \mathrm{hPA} / \mathrm{L} / \mathrm{s}$ and compliance of $50 \mathrm{~mL} / \mathrm{hPA}$. The critical care ventilator was configured for control pressure mode, inspiratory time (1 s), pressure (10 hPA), frequency (20 breaths/min), and PEEP (5 hPA). The inspiratory oxygen concentration $\left(\mathrm{FiO}_{2}\right)$ was measured as $25 \%, 50 \%, 75 \%$, and $100 \%$.

\section{Alarm verification}

A set of alarms were analyzed based on item 201.4.3, which was prescribed for ABNT NBR ISO IEC 80601-212:2014. Alarm conditions were generated according to the indications for each sub-item. The evaluated alarms are listed in Table 5.

\section{Calibration and verification}

Calibrated instruments are mandatory to perform maintenance and quality assessment procedures. The ventilator tester parameters were calibrated according
TABLE 5. List of alarms

\begin{tabular}{|c|c|c|}
\hline $\begin{array}{c}\text { Test } \\
\text { Number }\end{array}$ & Item & Test \\
\hline 1 & 201.11 .8 .101 .1 & $\begin{array}{c}\text { Technical alarm condition for power- } \\
\text { supply failure }\end{array}$ \\
\hline 2 & 201.11 .8 .101 .2 & Internal power supply \\
\hline 3 & 201.12 .4 .101 & Oxygen monitor \\
\hline 4 & 201.12 .4 .104 & $\begin{array}{c}\text { Maximum limited pressure } \\
\text { protective device }\end{array}$ \\
\hline 5 & 201.12 .4 .103 .1 & $\begin{array}{c}\text { Ventilators intended to provide a } \\
\text { tidal volume }>\text { 50 mL }\end{array}$ \\
\hline 6 & 201.12 .4 .105 & $\begin{array}{c}\text { High airway pressure alarm } \\
\text { condition and protective device }\end{array}$ \\
\hline 7 & 201.12 .4 .106 & PEEP alarm conditions \\
\hline 8 & 201.12 .4 .107 & Obstruction alarm condition \\
\hline 9 & 201.12 .101 & Disconnection alarm condition \\
\hline 10 & 201.13 .102 & Failure of one gas supply \\
\hline
\end{tabular}

to Table 6 with requirements based on the ABNT NBR IEC 60601-2-12:2014 and the International System of Units. The ventilator tester was calibrated following the available laboratory standard (LMR Metrologia, certificate number L613420, 2020-04-23). 
The electrical safety analyzer was calibrated for current, voltage, frequency, and resistance (IPT-Laboratorio de Metrologia Eletrica/CTMetro, certificate number 173117-101, 2019-05-16).

The IPT-POLI acquired a certified oxygen cylinder with a purity of $99.995 \%$ (Air Products Brazil Ltda, certificate number 256461, 2018-11-19) to verify the ventilator's galvanic cell tester that needs to be verified every day before the first use. A nitrogen gas sample was used to emulate the absence of oxygen for verification of the tester.

TABLE 6. Calibration points for the ventilator tester

\begin{tabular}{|c|c|}
\hline Parameters & Calibration points \\
\hline Flow (L/min) & $0.05,0.1,0.25,0.5,1,10,25,50,100$ \\
\hline Low pressure (mbar) & $0,5,10,15,20,30,60,120$ \\
\hline High pressure (bar) & $0,2,4,5,8,9.5$ \\
\hline $\begin{array}{c}\text { Barometric pressure } \\
\text { (mbar) }\end{array}$ & $650,700,750,800,850,900$ \\
\hline $\begin{array}{c}\text { Volume (mL) } \\
\text { Inspiratory time (s) }\end{array}$ & $0.005,0.01,0.02,0.03,0.05,0.2,0.3,1.5$ \\
\hline $\begin{array}{c}\text { Respiratory rate (breaths } \\
\text { min) }\end{array}$ & $10,15,20,25,30,60,80$ \\
\hline FiO $(\%)$ & $21,30,60,80,90,100$ \\
\hline
\end{tabular}

\section{Uncertainty of measurement (U)}

For the ventilator parameters, pressure $(\mathrm{hPa})$, volume $(\mathrm{mL}), \mathrm{FiO}_{2}(\%)$, PEEP $(\mathrm{hPa})$, and respiratory rate (breaths/min), three measurements were carried out and, consequently, the conventional quantity value and the measurement uncertainties were calculated.

To calculate measurement uncertainties, type A evaluation of measurement uncertainty, derived from a statistical source, and type B evaluation of measurement uncertainty, which is the information from the accuracy of the verification certificate and information from the instrument's manual, were used.

Type $A$ and $B$ uncertainties were integrated to provide a combined standard measurement uncertainty. ${ }^{5}$
For each test, leakage current, and resistance of the protective ground, only one measurement was taken, and type B uncertainties were adopted.

The uncertainties were calculated using combined and expanded uncertainties with a coverage factor $(\mathrm{k}=2$ and $95.45 \%$ ) as prescribed in the ISO GUM series - Guide to the expression of uncertainty in measurement. ${ }^{6}$

\section{Assessed critical care ventilators}

In total, nine critical care ventilators from two large public hospitals in São Paulo were assessed. Seven critical care ventilators (Vela, Carefusion, USA) were evaluated in April (Tables 1 and 2). In May, two critical care ventilators (Inter 5 Plus, Intermed, Brazil) were assessed, as shown in Tables 3 and 4 . The medical devices were named A, B, C, D, E, F, G, H, and I in this study.

The maximum errors for evaluating the first seven ventilators (A, B, C, D, E, F, and G) (Vela, Carefusion, USA) were obtained from its instruction for use and should be per the listed values: expiratory volume $\pm 10 \%$ of the monitored volume, respiratory rate $\pm 2 \mathrm{bpm}$, airway pressure $\pm 5 \mathrm{hPa}, P E E P \pm 2 \mathrm{hPa}$, inspiratory time $\pm 0.05 \mathrm{~s}$, and oxygen percentage $\pm 2 \%$.

For the last two ventilators ( $\mathrm{H}$ and I) (Inter 5 Plus, Intermed, Brazil), the maximum errors were: expiratory volume $\pm 10 \%$ of the monitored volume, airway pressure $\pm 0.05 \mathrm{cmH}_{2} \mathrm{O}, P E E P \pm 5 \mathrm{cmH}_{2} \mathrm{O}$, inspiratory time $\pm 0.05 \mathrm{~s}$, and oxygen percentage $\pm 5 \%$.

Volume control inflation type and pressure control inflation type were evaluated for the ventilators using preset modes: continuous mandatory ventilation pressure control (CMV-PC) and continuous mandatory ventilation volume control (CMV-VC).

\section{RESULTS}

All ventilators passed electrical safety tests for protective ground resistance, leakage current, patient leakage current, and enclosure leakage current.

Tables 7 and 8 summarize the measurement results for ventilators that did not comply with the stipulated limits. 
Because of the ventilators' problems, alarm verification was performed only on ventilators $\mathrm{A}, \mathrm{H}$, and I. All ventilators were not compliant with the oxygen level alarm.

\section{DISCUSSION}

The IPT-POLI adopted some of the essential performance requirements prescribed by item 201.4.3 ABNT NBR ISO IEC 80601-2-12:2014 to evaluate critical care ventilators. Tables 201.103 and 201.104 of items 201.12.1.101 and 201.12.1.102 of ABNT NBR ISO IEC 80601-2-12: 2014 were taken into consideration; however, within the first weeks, due to the limitations of the available test lung at IPT-POLI, the values of resistance and compliance were adapted according to the nearest values of resistance and compliance, as these configuration scenarios were shown in Tables 1 and 2. Another point was the time to carry out all 21 items in Tables 201.103 and 201.104. As hospitals urgently needed critical care ventilators due to COVID-19, only the first six test numbers were performed. All tests were performed with $\mathrm{FiO}_{2}$ adjusted to $21 \%$ (atmospheric concentration) to evaluate the accuracy of the control and the oxygen concentrations were evaluated separately.

After the test lung simulator (Dual Adult TTL, Michigan, USA) was acquired, all tests to verify the control's accuracy were conducted using Tables 3 and 4 . It was not possible to fully assess ventilators according to Tables 201.103 and 201.104 because the test lung did not attend the prescribed compliance values $(0.5,1$, and $3 \mathrm{hPa} / \mathrm{L} / \mathrm{s})$ for neonatal ventilators; nevertheless, the setup made it possible to assess critical care ventilators for adult configuration.

The purchased equipment (test lung and ventilator tester) to assess the volume and pressure control inflation-type modes were those with the shortest delivery time. The equipment was not the most capable; they lacked some features, such as external trigger input and well-sampled data; however, they met the quick application criteria.

Tables 7 and 8 indicate ventilators that did not comply with the delivered oxygen, volume, and pressure control inflation-type tests. This was expected because ventilators were out of use for more than two years and received only emergency maintenance without replacing the maintenance kit.

The $\mathrm{FiO}_{2}$ The measurement test was essential to evaluate the delivered oxygen; as shown in Tables 7 and 8, eight ventilators did not comply with the prescribed limits due to problems with internal leakages and control valves. External blenders controlled the percentage of oxygen in the ventilators (Inter 5 Plus, Intermed, Brazil); the blenders presented leakages in all configurations (21-100\%). Critical care ventilators commonly use galvanic cells to measure oxygen concentration, and those cells, depending on the manufacturer, have a life span of approximately 1-2 years. Also, eight ventilators did not monitor oxygen concentration correctly because of problems related to the galvanic cell or its absence.

Leakages in the ventilator breathing system (devices $\mathrm{E}$ and I) were observed during the tests.

One significant issue was noticed during tests with high medical oxygen concentrations, and the two ventilators presented inconsistent results. The results were doublechecked with a high-purity oxygen delivery system, and there were improvements in the performance of both ventilators. Therefore, we noticed that the pressure loss in the delivery system of medical gas during high flow occurred due to particle debris in the pipes, which were removed.

Even though pressure setup in critical care ventilators was performed extensively using pressure values in mbar or $\mathrm{cmH}_{2} \mathrm{O}$ by the clinicians, the ABNT NBR ISO 80601-2-12:2014 indicated pressure values in hPa. Even these units of measurement present a slight difference between them.

At the end of each critical ventilator quality assessment, all evaluated parameters were summarized in a quality assessment report and forwarded to the hospital's equipment control staff. Therefore, the quality assessment report could play an important role in hospital equipment usage decisions during the pandemic period. 
Alvarado, Rosa, Mello, Dias, Barbosa, Barros, Lemos, Vitorasso, Bartholomeu, Americano, Filho, Barros Moraes, Ferreira Junior, Moriya: Quality Assessment of Emergency Corrective Maintenance of Critical Care Ventilators within the Context of COVID-19 in São Paulo, Brazil

TABLE 7. Results of the critical care ventilators (Vela, Carefusion, USA) assessment

\begin{tabular}{|c|c|c|c|c|}
\hline \multicolumn{5}{|c|}{ Continuous mandatory ventilation volume control (CMV-VC) } \\
\hline \multirow[b]{2}{*}{ Ventilator } & \multirow{2}{*}{$\begin{array}{c}\text { Test } \\
\text { number }\end{array}$} & \multicolumn{3}{|c|}{ Results (mL) } \\
\hline & & \multicolumn{2}{|c|}{ Tidal volume } & $\begin{array}{c}\text { Uncertainty of measurement } \\
(\mathrm{U})\end{array}$ \\
\hline $\mathrm{C}$ & 1 & \multicolumn{2}{|c|}{570} & 13 \\
\hline $\mathrm{E}$ & 1 & \multicolumn{2}{|c|}{96.4} & 7.2 \\
\hline \multicolumn{5}{|c|}{ Continuous mandatory ventilation pressure control (CMV-PC) } \\
\hline \multirow[b]{2}{*}{ Ventilator } & \multirow{2}{*}{$\begin{array}{c}\text { Test } \\
\text { number }\end{array}$} & \multicolumn{3}{|c|}{ Results $(\mathrm{mL})$} \\
\hline & & \multicolumn{2}{|c|}{ Pressure } & $\begin{array}{c}\text { Uncertainty of measurement } \\
(\mathrm{U})\end{array}$ \\
\hline $\mathrm{E}$ & 1 & \multicolumn{2}{|c|}{37.1} & 1.5 \\
\hline $\mathrm{F}$ & 4 & \multicolumn{2}{|c|}{33.22} & 0.47 \\
\hline \multicolumn{5}{|c|}{ Oxygen concentration (\%) } \\
\hline Ventilator & Set value & Measured Value & $\begin{array}{l}\text { Uncertain } \\
\text { measureme }\end{array}$ & Monitored value \\
\hline A & 50 & 52.20 & 0.68 & 52 \\
\hline \multirow{2}{*}{ B } & 75 & 71.07 & 0.86 & 133 \\
\hline & 100 & 82.97 & 0.90 & 155 \\
\hline \multirow{4}{*}{$\mathrm{D}$} & 25 & 29.27 & 0.41 & 24 \\
\hline & 50 & 46.47 & 0.59 & 30 \\
\hline & 75 & 68.57 & 0.84 & 38 \\
\hline & 100 & 94.8 & 1.3 & 48 \\
\hline \multirow{4}{*}{$\mathrm{E}$} & 25 & 25.57 & 0.34 & $* *$ \\
\hline & 50 & 47.40 & 0.56 & ** \\
\hline & 75 & 68.40 & 0.80 & ** \\
\hline & 100 & 87.6 & 1.2 & $* *$ \\
\hline \multirow{4}{*}{$\mathrm{F}$} & 25 & 27.00 & 0.33 & ** \\
\hline & 50 & 62.03 & 0.76 & $* *$ \\
\hline & 75 & 89.8 & 1.1 & $* *$ \\
\hline & 100 & 99.9 & 1.2 & ** \\
\hline \multirow{2}{*}{ G } & 50 & 54.50 & 0.81 & 63 \\
\hline & 75 & 82.83 & 0.97 & 100 \\
\hline
\end{tabular}

(*) This refers to the monitored $\mathrm{O}_{2} \%$ value displayed on the ventilator..

${ }^{* *}$ ) The monitored $\mathrm{O}_{2} \%$ value is not shown because the galvanic cell was not installed. 
Alvarado, Rosa, Mello, Dias, Barbosa, Barros, Lemos, Vitorasso, Bartholomeu, Americano, Filho, Barros Moraes, Ferreira Junior, Moriya: Quality Assessment of Emergency Corrective Maintenance of Critical Care Ventilators within the Context of COVID-19 in São Paulo, Brazil

TABLE 8. Results of the critical care ventilators (Inter 5 Plus, Intermed, Brazil) assessment

\begin{tabular}{|c|c|c|c|}
\hline \multicolumn{4}{|c|}{ Continuous mandatory ventilation volume control (CMV-VC) } \\
\hline \multirow[b]{2}{*}{ Ventilator } & \multirow{2}{*}{$\begin{array}{c}\text { Test } \\
\text { number }\end{array}$} & \multicolumn{2}{|c|}{ Results (mL) } \\
\hline & & Tidal volume & $\begin{array}{c}\text { Uncertainty of measurement } \\
\text { (U) }\end{array}$ \\
\hline \multirow{6}{*}{$\mathrm{H}$} & 2 & 392 & 10 \\
\hline & 3 & 407.1 & 9.8 \\
\hline & 4 & 447 & 11 \\
\hline & 6 & 261.8 & 6.7 \\
\hline & 7 & 265.6 & 8.0 \\
\hline & 8 & 170.5 & 4.3 \\
\hline \multirow{4}{*}{ I } & 2 & 395.3 & 12 \\
\hline & 3 & 421 & 10 \\
\hline & 6 & 262.4 & 6.1 \\
\hline & 8 & 168.1 & 4.0 \\
\hline
\end{tabular}

\begin{tabular}{|c|c|c|c|}
\hline \multicolumn{4}{|c|}{ Continuous mandatory ventilation pressure control (CMV-PC) } \\
\hline \multirow[b]{2}{*}{ Ventilator } & \multirow{2}{*}{$\begin{array}{c}\text { Test } \\
\text { number }\end{array}$} & \multicolumn{2}{|c|}{ Results (mL) } \\
\hline & & Pressure & $\begin{array}{c}\text { Uncertainty of measurement } \\
\text { (U) }\end{array}$ \\
\hline \multirow{3}{*}{$\mathrm{H}$} & 1 & 15.8 & 0.7 \\
\hline & 3 & 32.1 & 0.8 \\
\hline & 8 & 35.0 & 0.5 \\
\hline \multirow{3}{*}{ I } & 1 & 17.4 & 0.9 \\
\hline & 3 & 32.7 & 0.9 \\
\hline & 8 & 37.0 & 0.7 \\
\hline
\end{tabular}

\begin{tabular}{|c|c|c|c|c|}
\hline \multicolumn{5}{|c|}{ Oxygen concentration (\%) } \\
\hline Ventilator & Set value & Measured Value ${ }^{\star}$ & $\begin{array}{c}\text { Uncertainty of } \\
\text { measurement }(U)\end{array}$ & Monitored value \\
\hline \multirow{3}{*}{$\mathrm{H}$} & 25 & 22.6 & 0.3 & ** \\
\hline & 50 & 44.4 & 0.6 & ** \\
\hline & 75 & 69.7 & 1.7 & ** \\
\hline \multirow{3}{*}{ I } & 25 & 28.9 & 3.7 & $* *$ \\
\hline & 75 & 69.2 & 0.5 & $* *$ \\
\hline & 100 & 93.9 & 1.1 & ** \\
\hline
\end{tabular}

$\left.{ }^{*}\right)$ This refers to the monitored $\mathrm{O}_{2} \%$ value displayed on the ventilator..

${ }^{* *}$ ) The monitored $\mathrm{O}_{2} \%$ value is not shown because the galvanic cell was not installed. 


\section{CONCLUSION}

Although all medical devices underwent corrective maintenance, eight out of nine failed the delivered oxygen test. Moreover, eight ventilators did not monitor oxygen, and four ventilators were not compliant with volume control and pressure inflation tests. The results are summarized in Tables 7 and 8.

Notwithstanding the urgent requirement of critical care ventilators for COVID-19, the performed tests revealed the necessity of conducting quality assessment after the maintenance of critical care ventilators to avoid risk to patients.

Justified by the fact that severe COVID-19 cases required safe delivery of ventilation oxygen support, ${ }^{7,8}$ the tests listed in this study aimed to cover the basis of ventilation assessment to guarantee the accuracy of the critical care ventilator's performance.

The minimum infrastructure and instrument requirements to perform a quality assessment of emergency corrective maintenance of critical care ventilators during the beginning of COVID-19 in Brazil are presented herein.

\section{CONFLICT OF INTEREST}

The authors declare that they have no conflict of interest.

\section{ACKNOWLEDGEMENTS}

This study was financed in part by: the endowment fund of University of Sao Paulo Engineering School" Amigos da Poli" (+Ventiladores project) and Sao Paulo State Government (42960P - Comitê de Crise do COVID-19).

\section{REFERENCES}

1. Rache B, Rocha R, Nunes L et al. Necessidades de Infraestrutura do SUS em Preparo ao COVID-19: Leitos de UTI, Respiradores e Ocupação Hospitalar. São Paulo: Instituto de Estudos para Políticas de Saúde;
2020. Available from: https://ieps.org.br/pesquisas/ necessidades-de-infraestrutura-do-sus-em-preparoao-covid-19-leitos-de-uti-respiradores-e-ocupacaohospitalar/.

2. Associação Brasileira de Normas Técnicas. NBR IEC 60601-1: 2010+A1: 2016 Requisitos gerais para segurança básica e desempenho essencial. ABNT; 2010. Available from: https://www.abntcatalogo.com.br/ norma.aspx?ID=355495

3. Associação Brasileira de Normas Técnicas. NBR ISO IEC 62353: 2019 Ensaio recorrente e ensaio após reparo de equipamento eletro médico. ABNT; 2019. Available from: https://www.abntcatalogo.com.br/ norma.aspx?ID=416843

4. Associação Brasileira de Normas Técnicas. NBR ISO 80601-2-12: 2014 Requisitos particulares para a segurança básica e o desempenho essencial de ventiladores para cuidados críticos. ABNT; 2014. Available from: https://www.abntcatalogo.com.br/norma. aspx?ID=326196

5. Vocabulário Internacional de Metrologia: Conceitos fundamentais e gerais e termos associados (VIM 2012). Rio de Janeiro: INMETRO; 2012. Available from: http://www.inmetro.gov.br/inovacao/publicacoes/ vim_2012.pdf

6. Avaliação de dados de Medição: Guia para a expressão de incerteza de medição. Rio de Janero: INMETRO.; 2012. Available from: http://www.inmetro.gov.br/ noticias/conteudo/iso_gum_versao_site.pdf.

7. Lyons $\mathrm{C}$, Callaghan $\mathrm{M}$. The use of high-flow nasal oxygen in COVID-19. Anaesthesia. 2020; 75:843-847. Available from: https://onlinelibrary.wiley.com/doi/ full/10.1111/anae.15073

8. Baker T, Schell C, Petersen D, et al. Essential care of critical illness must not be forgotten in the COVID-19 pandemic. The Lancet. 2020; 395:1253-1254. Available from: https://www.thelancet.com/pdfs/journals/ lancet/PIIS0140-6736(20)30793-5.pdf 